J. Indones. Math. Soc.

Vol. 16, No. 1 (2010), pp. 39-49.

\title{
A TRAVELING PULSE BEHAVIOR OF THE SPREAD OF THE AVIAN FLU VIRUSES AMONG FLOCK AND HUMAN
}

\author{
S.R. Pudjaprasetya And A.Y. Gunawan \\ Industrial \& Financial Mathematics Research Group, \\ Faculty of Mathematics and Natural Sciences, \\ Institut Teknologi Bandung, Jalan Ganesha 10 Bandung, Indonesia, \\ \{sr_pudjap, aygunawan\}@math.itb.ac.id
}

\begin{abstract}
We propose two disease transmission models: the SI model with diffusive terms as a model for transmission of avian influenza viruses among flock with constant population density, and the host-vector SI model with diffusive terms for transmission among flock and human. There is a threshold number that determine whether the diseases become epidemic or not. It depends on three parameters: the average length of the infective period, the contact parameter, and the density of susceptible population at the initial time. With diffusive terms in the model, the spatial spread of the infection is obvious. Threshold number greater than one is also the necessary condition for the spreading of infection in the form of a traveling pulse. Its minimum velocity can be determined. We implement the MacCormack method, and simulate the generation of a traveling pulse starting from one infected bird. Numerically, we obtain the percentage of survival in flock and human after the epidemic. We also simulate the minimal portion of immunization in order to prevent further spread.
\end{abstract}

Key words and Phrases:SI model, host-vector model, threshold number, avian flu, traveling wave

2000 Mathematics Subject Classification: Primary, 92D30, Secondary, 35B05, 35F25, 35A18, 75R50 Received: 20-04-2010, accepted: 31-08-2010. 


\begin{abstract}
Abstrak. Paper ini menyajikan dua model penyebaran virus flu burung. Model pertama adalah model penyebaran virus pada unggas dengan jumlah populasi konstan berupa model SI dengan tambahan suku difusi. Model kedua adalah model penyebaran virus pada unggas dan manusia berupa model SI host-vector dengan suku difusi. Diperoleh bilangan threshold yang dapat digunakan untuk menentukan apakah penyakit akan berkembang menjadi epidemi atau tidak. Bilangan threshold itu bergantung pada tiga parameter: rata-rata lama waktu terinfeksi, parameter kontak, dan proporsi populasi susceptible saat awal. Dengan adanya suku difusi, selain berubah terhadap waktu, maka infeksi akan menyebar pula secara spasial. Ternyata nilai bilangan threshold yang lebih besar dari satu juga menjadi syarat perlu bagi penyebaran infeksi kesekelilingnya dalam pola gelombang berjalan. Kecepatan minimum dari gelombang berjalan tersebut juga dapat ditentukan. Kedua model tak linier di atas diselesaikan secara numerik dengan metoda MacCormack. Hasil simulasi menunjukkan pola penyebaran infeksi berbentuk gelombang berjalan diantara unggas dan manusia sehat, yang berawal dari satu unggas yang terinfeksi. Hasil simulasi juga dapat menghasilkan prosentase unggas dan manusia yang tetap bertahan setelah epidemi. Proporsi minimal unggas yang harus divaksinasi untuk mencegah penyebaran virus, juga disimulasikan.
\end{abstract}

Kata kunci:model SI, model SI host-vector, bilangan threshold, flu burung, gelombang berjalan

\title{
1. Introduction
}

A severe form of avian influenza or bird flu called H5N1 has affected poultry flock and other flock in several countries since 2003. Avian influenza starts to infect people through a direct contact with infected flock or contaminated surface. Therefore, a thorough investigation on the spread of avian influenza viruses among flock or poultry is very important.

Avian influenza viruses circulate among flock worldwide. Certain birds carry the virus in their intestines and shed it in their secretions. Susceptible birds can become infected with avian influenza virus when they have contact with contaminated area from infected flock. Most often, the wild birds that are host to the virus do not get sick, but they can spread the influenza to other flock. Infection with certain avian influenza A (H5N1) viruses can cause widespread disease and death among domesticated birds (chickens).

Mathematical models for contagious diseases are common in many literatures, such as [1], [2], [5], and [6]. They derived the model as ordinary differential equations in the form of SIR, SI, and SEIR models. For a spread of avian flu disease, Clancy et.al. in [4] studied the spread of H5N1 viruses in a seabird colony using the SEIR model. Cahill et.al. in [3] studied the spread of influenza using the agestructured SIR model with two-dimensional spatial dependence. Norberto A.M. in [7] et.al. studied the spatial spread of dengue disease using the host vector model 
with addition of diffusive terms, and considered the spread of the disease in terms of traveling waves.

In [8] a preliminary study of the dynamics of avian flu in flock and human was addressed. In this paper, we extend the SI model in [8] by including diffusive terms as the model for spatial and temporal spread of avian flu in flocks. The inclusion of the diffusive term in our present model is motivated by two reason; first, from the mathematical point of view the resulting equations are more complex than the SIR/SEIR model, since the present model is described by a set of partial differential equations. Thus, the analysis will rather be different; second, since in the reality the virus can mobile from one place to other places, than the study of spatial spread may become important. For the moment, we consider the one-dimensional spatial dependence case. For the spread of avian flu in flock and human, we use the host-vector model, with flock as the vector and human as host. We are particularly interested in the spread of the infection in the form of a 'traveling wave', for both flock and human having constant densities. Here the necessary condition for the existence of the traveling wave are obtained. Using the initial condition in which one infection occurs at a certain place, we simulate the growth of the infection, follows by the spreading of the infection to the left and to the right in the form of traveling waves. Numerical simulations presented here show the appearance of traveling pulses of infection in flock and in human. Further, we get the percentage of flock and human that could survive from the epidemic. As a control strategy, a certain portion of the susceptible population, nearby the infected area with a certain radius, should be immunized in order to prevent the spread of the epidemic. The effect of immunizing a certain portion of the susceptible are simulated as well.

\section{Transmission of avian flu among flock}

In this study we assume that the incubation period of the infectious viruses is zero, and demographic effect is neglected. Neglecting demographic effect is reasonable because the spreading time of this disease is much shorter than the time needed for natural growth of the population. The flock population being studied is divided in two classes, labeled by $S$ and $I$. Let $S(x, t)$ denotes the density of flock that are susceptible to the disease at a position $x$ at time $t ; I(x, t)$ denotes the density of infected and also infectious flock. These flock are able to spread the disease by contact with susceptible. The spatial dispersal of $S$ and $I$ are modeled by simple diffusions, with the same diffusion coefficient $D$, a positive number. We model the temporal and spatial spread of the disease as

$$
\begin{aligned}
& S_{t}=-\beta S I+D S_{x x} \\
& I_{t}=\beta S I-\alpha I+D I_{x x} .
\end{aligned}
$$

The amount $\beta S I$ leaves the susceptible class and moves over to infective class per unit time. Parameter $\beta$ is called the infection rate. The amount $\alpha I$ of infective leaves the infective class per unit time through death from the disease, and the 
parameter $\alpha$ is called the removal rate of infective or the death rate. The value $1 / \alpha$ can be interpreted as the average time an individual suffers from the illness. Consider the second equation of (1) without diffusion term. The number of infection $I(t)$ increases if and only if $\beta S_{0}>\alpha$. Hence, the threshold number is

$$
R_{0}=\beta S_{0} / \alpha,
$$

and epidemic happens if and only if $R_{0}>1$. The threshold number $R_{0}$ depends linearly on the infection rate $\beta$ and the initial susceptible density $S_{0}$, and depends inversely on the death rate $\alpha$. For a contagious disease epidemic is more likely to happen when susceptible density is higher, and when the death rate of an infective is larger.

2.1. A traveling pulse of infection. Among flock, avian flu that initially happen at one place will spread to its surrounding. We will concentrate on how this disease spread. In particular, will it spread in the form of a traveling wave, and what is its velocity. Traveling wave form of the spreading is possible for population with constant density. Here, we formulate the necessary condition for the existence of the traveling wave solution of (1). A thorough investigation on the existence of such a traveling wave can be obtained in [6].

In the following, we seek for traveling wave solutions of (1) with velocity $c$. Substituting $I(x, t)=I(\xi), S(x, t)=S(\xi)$, with $\xi=x-c t$ into (1), we obtain

$$
\left\{\begin{array}{l}
D S^{\prime \prime}+c S^{\prime}-\beta S I=0 \\
D I^{\prime \prime}+c I^{\prime}+(\beta S-\alpha) I=0
\end{array}\right.
$$

Imagine 'a pulse of infection' propagates into the susceptible population with constant density $S_{0}$, so we have

$$
S(\infty)=S_{0}, \quad I(\infty)=0 .
$$

Note that the steady state solution of (1) in the spatially homogeneous situation is $\left(S_{0}, I=0\right)$, with $S_{0}$ any real number. And $S_{0}$ should be non negative in this epidemic model. Now, consider perturbation around the equilibrium point $(S=$ $\left.S_{0}, I=0\right)$. Up to the linear order, the second equation of (3) becomes

$$
D I^{\prime \prime}+c I^{\prime}+\left(\beta S_{0}-\alpha\right) I \approx 0 \text {. }
$$

Solution of $(5)$ is

$$
I(\xi) \approx \exp \left[\frac{1}{2 D}\left(-c \pm\left(c^{2}-4 D\left(\beta S_{0}-\alpha\right)\right)^{1 / 2}\right) \xi\right]
$$

Having obtained $I(\xi)$, we can determine the linear order of $S$ from the first equation of (3). But for the moment, we only focus on finding the condition for the existence of the traveling pulse of infection. Hence, we proceed as follows. The function $I(\xi)$ should never be negative, since it physically has no meaning. Hence, the power 
of the exponential term should never be a complex number. So, we obtain the necessary condition for the traveling wave to exist is

$$
c \geq c_{\min }
$$

where

$$
c_{\min } \equiv 2\left(\beta S_{0} D\right)^{\frac{1}{2}} \sqrt{1-\frac{\alpha}{\beta S_{0}}},
$$

is the minimal wave speed of the traveling wave. Thus, the necessary condition for the existence of traveling wave solution, when expressed in threshold number is

$$
R_{0} \equiv \beta S_{0} / \alpha>1 \text {. }
$$

In dynamical system terminology, the traveling pulse of infection is a trajectory from the unstable saddle point solution $(S=0, I=0)$ to the stable node solution $\left(S=S_{0}, I=0\right)$. Several interpretations of (8) are as follows. The more infectious the disease is, $\beta$ larger, the more likely it will spread. The more fatal the disease is, $\alpha$ larger the less chance it becomes an epidemic, and the less likely it will spread. A large number of urban population $S_{0}$ will increase the threshold number and worsening the outbreak.

2.2. Numerically generated traveling wave. In this section, we will discretize equation (1) using the MacCormack method and we will present the numerical generation of traveling waves starting from one infection. The MacCormack method is an explicit, two-level, two-step method with accuracy $O\left(\Delta x^{2}, \Delta t^{2}\right)$. It is convergent and conditionally stable. The first step is predicting the values of $S_{i}^{n+1}$ and $I_{i}^{n+1}$ using FTCS (Forward Time Center Space), and that is

$$
\begin{aligned}
& \overline{S_{i}^{n+1}}=S_{i}^{n}-\beta \Delta t S_{i}^{n} I_{i}^{n}+C\left(S_{i+1}^{n}-2 S_{i}^{n}+S_{i-1}^{n}\right) \\
& \overline{I_{i}^{n+1}}=I_{i}^{n}+\beta \Delta t S_{i}^{n} I_{i}^{n}-\alpha \Delta t I_{i}^{n}+C\left(I_{i+1}^{n}-2 I_{i}^{n}+I_{i-1}^{n}\right),
\end{aligned}
$$

with $C=\frac{D \Delta t}{\Delta x^{2}}$. The second step, which is the corrector step of the MacCormack method is

$$
\begin{gathered}
S_{i}^{n+1}=\frac{1}{2}\left(S_{i}^{n}+\overline{S_{i}^{n+1}}-\beta \Delta t \overline{S_{i}^{n+1} I_{i}^{n+1}}+C\left(\overline{S_{i+1}^{n+1}}-2 \overline{S_{i}^{n+1}}+\overline{S_{i-1}^{n+1}}\right)\right) \\
I_{i}^{n+1}=\frac{1}{2}\left(I_{i}^{n}+\overline{I_{i}^{n+1}}+\beta \Delta t \overline{S_{i}^{n+1} I_{i}^{n+1}}-\alpha \Delta t \overline{I_{i}^{n+1}}+C\left(\overline{I_{i+1}^{n+1}}-2 \overline{I_{i}^{n+1}}+\overline{I_{i-1}^{n+1}}\right)\right)
\end{gathered}
$$

Hence, the SI-model will be integrated using (9-12) on the computation domain $(x, t) \in[0,50 \mathrm{~km}] \times[0,37.5$ days $]$. For the left and right boundaries we use the absorbing boundary conditions.

Example 1: Consider a flock with population density $S_{0}=100$. For simulation we take $\alpha=0.5$, since an infected flock usually dies after 2 days. Considering avian flu as an airborne disease, we take the threshold number $R_{0}=5.5$. Taking these two parameters give us the contact-parameter $\beta=0.027$. Next, we choose the spatial spread parameter $D=1 / 5$. Suppose that initially there is one infected bird in the middle of the spatial domain. Hence, the initial condition is $S(x, 0)=S_{0}$, 


\begin{tabular}{lll}
\hline Parameter & Description & Value \\
\hline$\beta$ & infection rate & $0.027 \mathrm{~km} /$ day-flock \\
$\alpha$ & death rate & $0.5 /$ day \\
$D$ & spatial spread parameter & $1 / 5 \mathrm{~km}^{2} /$ day \\
$S_{0}$ & initial density of susceptible & 100 flock $/ \mathrm{km}$ \\
\hline
\end{tabular}

TABle 1. Parameters for Example 1.

$I(x, 0)=0$, for all $0 \leq x \leq 50 \mathrm{~km}$ except that $S(25 \mathrm{~km}, 0)=99, I(25 \mathrm{~km}, 0)=1$. For this computation we use $\Delta t=0.1$ and $\Delta x=0.5$. The result of numerical computation is given in Figure 1. It clearly shows that the initial one infection will lead to an epidemic, a pulse of infective. This pulse grows, then it moves to the right and to the left with velocity $1.3 \mathrm{~km} /$ day. This is exactly the minimum velocity $c_{\text {min }}$ obtained from $(7)$. The percentage of susceptible that survive after the epidemic had passed is $0.8 \%$, which could be interpreted as no birds could survive.

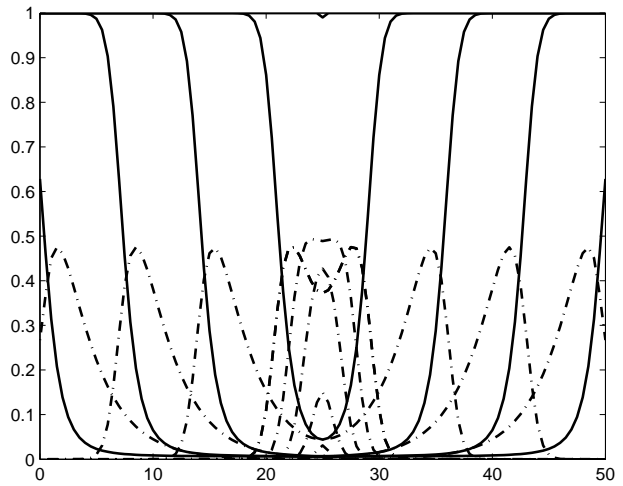

Figure 1. The curves of $S\left(x, t_{i}\right) / S_{0}$ (solid line) and $I\left(x, t_{i}\right) / S_{0}$ (dotted line) as functions of $x \in[0,50 \mathrm{~km}]$ for subsequent time $t_{0}=0<t_{1}<\cdots<t_{n}=37.5$ day.

Figure 1 clearly shows the evolution of an initial infection that spread to its surrounding in the form of traveling waves. This is the numerical evidence of the generation of a traveling pulse of infection in a constant density population. Several numerical computations with different value of $R_{0}$ suggest that $R_{0}>1$ is also a sufficient condition.

2.3. Control Strategies. Suppose that there is an outbreak at a certain place. What kind of control strategies can be applied to its surrounding? In the case of no-diffusive terms a fraction $1-1 / R_{0}$ of the susceptible population should be 
immunized in order to prevent the epidemic. Here we simulate the effect of immunizing a certain portion of susceptible population. Using the same parameters as in Example 1, the minimum portion is $\left(1-1 / R_{0}\right)=0.8182$. Hence we immunize $82 \%$ of the susceptible population in the surrounding of the infected domain, say within a radius of $5 \mathrm{~km}$. In Figure 2 (Left) we can see that the infection dies out. Compare with Figure 2 (Right) in which we have immunized only $70 \%$. We can see that first the infection decreases but then it starts to grow as a new source of infection to its surrounding.
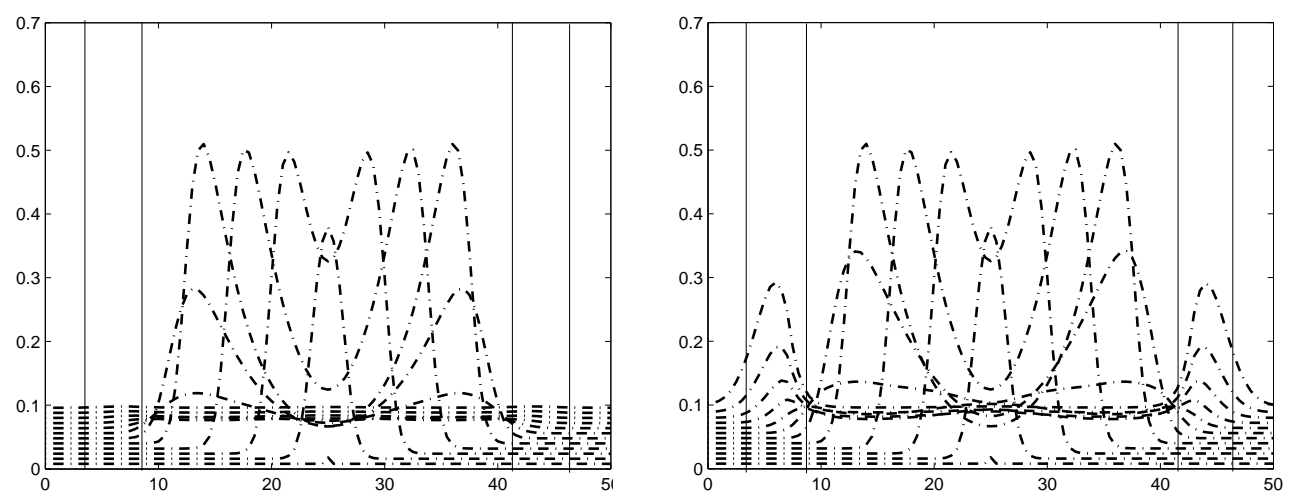

FiguRE 2. The curves of $I\left(x, t_{i}\right) / S_{0}$ as functions of $x \in[0,50 \mathrm{~km}]$ for subsequent time $t_{0}=0<t_{1}<\cdots<t_{n}=37.5$ day. The areas between vertical lines indicate where the immunization take place. Left: after immunizing $1-1 / R_{0}=82 \%$ of the susceptible population, Right: after immunizing $70 \%$.

\section{Transmission of avian flu among human and flock}

In this section we study the spatial and temporal spread of avian flu among human and flock. We assume that human is infected by H5N1 viruses from contact with an infected flock, and there is no transmission human-to-human. Hence, a suitable model is the host-vector model, with human as hosts, and flock as vectors. Let $S_{V}$ and $I_{V}$ denote the density of susceptible and infective (also infectious) birds at time $t$, respectively. Whereas $S_{H}, I_{H}$ and $R_{H}$ denote the density of susceptible, infective and removed human at time $t$, respectively. Subscripts used are $V$, for 'vector' and $H$, for 'host'. "Removed human" here means a human who died due to the disease or a human who has recovered from the illness. Re-infection of avian flu in human is not likely to happen. This is based on private communications with people working in the pandemic diseases research. So, in this model the recovered human is put in the same class as the dead human because mathematically they 
are the same category. The proposed model is

$$
\begin{aligned}
S_{V_{t}} & =-\beta_{V} S_{V} I_{V}+D_{V} S_{V_{x x}} \\
I_{V_{t}} & =\beta_{V} S_{V} I_{V}-\alpha_{V} I_{V}+D_{V} I_{V_{x x}} \\
S_{H_{t}} & =-\beta_{H} S_{H} I_{V}+D_{H} S_{H_{x x}} \\
I_{H_{t}} & =\beta_{H} S_{H} I_{V}-\alpha_{H} I_{H}-\gamma_{H} I_{H}+D_{H} I_{H_{x x}} \\
R_{H_{t}} & =\left(\alpha_{H}+\gamma_{H}\right) I_{H}+D_{H} R_{H_{x x}}
\end{aligned}
$$

The first two equations are the model for transmission of avian flu among flock as before, now with parameters $\alpha_{V}$ and $\beta_{V}$. The term $\beta_{H} S_{H} I_{V}$ in the third equation denotes the number of new infections in human per unit time, due to contact with infected flock. The term $\alpha_{H} I_{H}$ denotes the number of infected human who die because of the disease per unit time. The term $\gamma_{H} I_{H}$ denotes the number of infected human who recover from the disease per unit time. Parameters $\beta_{H}, \alpha_{H}$ and $\gamma_{H}$ are called the infection rate, the death rate and the recovery rate in human, respectively. Note that the equation for $R_{H}$ can be skipped from the model because the value of $R_{H}(t)$ does not involve in the other equations.

3.1. Traveling pulses of infection. Again here we are interested in finding a condition that the infections in flock and human travel to its surrounding in the form of traveling waves with the same speed. Let $S_{V_{0}}$ and $S_{H_{0}}$ denotes the initial density of susceptible flock and human, respectively. Next, we will look for traveling wave solutions of (13) with velocity $c$. Substituting $I_{V}(\xi), S_{V}(\xi), I_{H}(\xi), S_{H}(\xi)$ with $\xi=x-c t$, into the equation (13) will yield

$$
\left\{\begin{array}{l}
D_{V} S_{V}^{\prime \prime}+c S_{V}^{\prime}-\beta_{V} S_{V} I_{V}=0 \\
D_{V} I_{V}^{\prime \prime}+c I_{V}^{\prime}+\left(\beta_{V} S_{V}-\alpha_{V}\right) I_{V}=0 \\
D_{H} S_{H}^{\prime \prime}+c S_{H}^{\prime}-\beta_{H} S_{H} I_{V}=0 \\
D_{H} I_{H}^{\prime \prime}+c I_{H}^{\prime}+\beta_{H} S_{H} I_{V}-\left(\alpha_{H}+\gamma_{H}\right) I_{H}=0
\end{array}\right.
$$

The steady state of (13) are $\left(S_{V}, I_{V}=0, S_{H}, I_{H}=0\right)$, for any number of $S_{V}$ and $S_{H}$. Assume an infection enters susceptible flock population and human with density $S_{V_{0}}$ and $S_{H_{0}}$, respectively. Expanding the second equation of (14) around the critical point $\left(S_{V}(\infty)=S_{V_{0}}, I_{V}(\infty)=0, S_{H}(\infty)=S_{H_{0}}, I_{H}(\infty)=0\right)$ will gives us an equation analogous to (5). Using similar argument like in Section 2.1, we obtain the necessary condition for a traveling wave solution to exist, and that is, the corresponding threshold number should be greater than one or

$$
\frac{\beta_{V} S_{V_{0}}}{\alpha_{V}}>1 .
$$

Analogous argument can be applied to the other three equations of (13), but these do not give any other condition. And the minimal velocity of the traveling wave is the analogous form of (7).

Example 2: Consider a population of flock with density $S_{V_{0}}=100$ and human with density $S_{H_{0}}=30$. The parameters used are given in Table 2. We take $\alpha_{H}=1 / 7$, since the average length of the infected period in human before dying is 7 


\begin{tabular}{lll}
\hline Parameter & Description & Value \\
\hline$\beta_{V}$ & infection rate in flock & $0.027 \mathrm{~km} /$ day-flock \\
$\alpha_{V}$ & death rate in flock & $0.5 /$ day \\
$D_{V}$ & spatial spread parameter in flock & $1 / 5 \mathrm{~km}^{2} /$ day \\
$S_{V_{0}}$ & initial density of flock & $100 \mathrm{flock} / \mathrm{km}$ \\
$\beta_{H}$ & infection rate in human & $0.01 \mathrm{~km} /$ day-human \\
$\alpha_{H}$ & death rate in human & $1 / 7 /$ day \\
$\gamma_{H}$ & recovery rate in human & $0.09 /$ day \\
$D_{H}$ & spatial spread parameter in human & $1 / 5 \mathrm{~km}^{2} /$ day \\
$S_{H}$ & initial density of human & $30 \mathrm{human} / \mathrm{km}$ \\
\hline
\end{tabular}

TABLE 2. Parameters for Example 2

days. The time needed by an infected human to recover, can be used to predict $\gamma_{H}$. But here, we use WHO data ${ }^{1}$ and predict $\gamma_{H}=0.09$. The analogous MacCormack method is applied to $(13)$ in the domain $(x, t) \in[0,50 \mathrm{~km}] \times[0,37.5$ day $]$. For this computation we use $\Delta t=0.1$ and $\Delta x=0.5$. We choose an initial condition: all flock and human are susceptible at the beginning, except one flock in the middle of the area was infected. So, the initial condition is $S_{V}(x, 0)=S_{V_{0}}, I_{V}(x, 0)=0$, $S_{H}(x, 0)=S_{H_{0}}, I_{H}(x, 0)=0$ for all $0 \leq x \leq 50 \mathrm{~km}$, except that $S_{V}(25 \mathrm{~km}, 0)=99$, $I_{V}(25 \mathrm{~km}, 0)=1$. The results are given in Figure 3 .

It clearly shows that the initial infection will lead to an epidemic, the growth of infective, in both flock and human population. Then, each pulse of infective is split into right and left traveling waves. The infection spread to its surrounding with velocity $\approx 1.3 \mathrm{~km} /$ day. Numerically, we observe that after the epidemic $5 \%$ of flock and $80 \%$ of human are survive.

\section{Conclusions}

The study of the spatial spread of avian flu for two cases: among flock and among flock and human with diffusive terms results the following. For both models, epidemic will happen if and only if the infection rate times the number of susceptible flock is greater than the death rate of the infected flock. The above condition is also a necessary condition for the spreading of epidemic in the form of a traveling pulse. Starting from one infection, numerical simulation shows the epidemic: the infection grows, and then spreads to the left and to the right with the same velocity, in the form of a traveling pulse of infection. It shows the same phenomenon like a wave in fluid. The minimal portion of the population that should be immunized in order to prevent the spread of the epidemic is confirmed in the simulations. For model of avian flu spreading among flock and human, numerical simulations show that starting from the one infected bird, the number of infective in human and flock are

\footnotetext{
${ }^{1}$ WHO data dated Jan 15, 2007 [?]: 'During the last 5 years there are 267 infected human, and 161 of them died'. Hence, we predict $\gamma_{H} \approx(267-161) / 161$.
} 

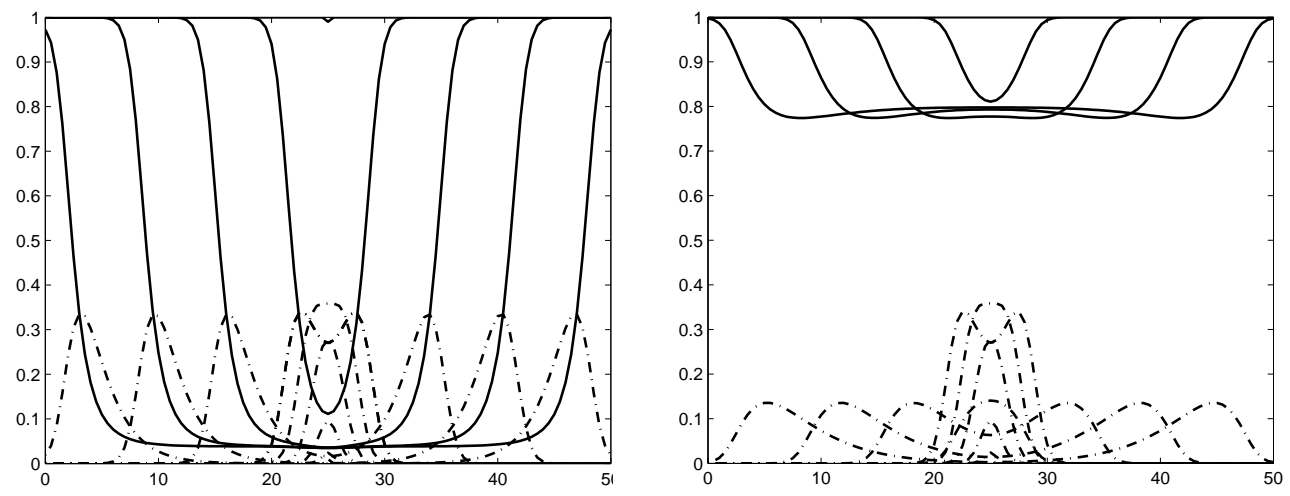

Figure 3. (Left) The curves of $S_{V}\left(x, t_{i}\right) / S_{V_{0}}$ (solid line) and $I_{V}\left(x, t_{i}\right) / S_{V_{0}}$ (dotted line) for subsequent time $t_{0}<t_{1}<\cdots<$ $t_{n}=37.5$ day. (Right) The curves of $S_{H}\left(x, t_{i}\right) / S_{H_{0}}$ (solid line) and $I_{H}\left(x, t_{i}\right) / S_{H_{0}}$ (dotted line) for subsequent time $t_{0}<t_{1}<$ $\cdots<t_{n}=37.5$ day.

increasing in time, and further, this pulse of infection spreads to its surrounding in the form of traveling pulses.

\section{Acknowledgement}

This research is supported by Riset KK ITB, No. 271/K01.7/PL/2009. The authors would like to thank Nurhabibah for fruitful discussions during this research.

\section{References}

[1] Anderson, R.M. ,and May, R.M., "Population Biology of Infectious Diseases: Part I", Nature 280, (1979), 361-367.

[2] Brauer, F. and Castillo-Chávez, C., Mathematical Models in Population Biology and Epidemiology, Text in Applied Math. 40, Springer-Verlag, New York, Berlin, Heidelberg, 2000.

[3] Cahill, E., Crandall, R., Rude, L., and Sullivan, A., "Space-time influenza model with demographic, mobility, and vaccine parameters", Proc. 5th Ann. Hawaii Intl. Conf. on Math., Stat., and related fields, t.b.p. 2006.

[4] Clancy, C.F., O'Callaghan, M.J.A., and Kelly, T.J., "A Multi-scale problem arising in a model of avian flu virus in a seabird colony", Journal of Physics: Conference Series 55, (2006), 45-54

[5] Kermack, W.O., and McKendrick, A.G., "A Contribution to the Mathematical Theory of Epidemics", Proc. Roy. Soc. Lond. A 115, (1927), 700-721.

[6] Murray, J.D., Mathematical Biology, $2^{\text {nd }}$ Corrected Edition, Springer-Verlag, 1980.

[7] Maidana, N.A., and Yang, H.M., "Describing the geographic spread of dengue desease by traveling waves", Mathematical Biosciences 215, (2008), 64-77. 
[8] Pudjaprasetya, S.R., "The Modified SIR Model for Transmission of Avian Influenza, a preliminary study", Proceedings ICMNS, (2006). 